\title{
Penggunaan Tepung Limbah Kulit Kopi (Coffea arabica L) Dalam Ransum Terhadap Kualitas Telur Burung Puyuh (Coturnix coturnix Javonica)
}

\section{Chandra Mardinsyah Nasution ${ }^{1}$, Aisyah Nurmi ${ }^{2}$, Muharram Fajrin Harahap ${ }^{3}$}

\author{
${ }^{1}$ Alumni Fakultas Peternakan Program Studi Peternakan Universitas Muhammadiyah \\ Tapanuli Selatan, e-mail :chandra.namikaze@yahoo.com \\ ${ }^{2}$ Dosen Program Studi Peternakan Fakultas Peternakan Universitas Muhammadiyah \\ Tapanuli Selatan,e-mail :aisyah.nurmi@um-tapsel.ac.id \\ ${ }^{3}$ Dosen Program Studi AgroteknologiFakultas Pertanian Universitas Muhammadiyah \\ Tapanuli Selatan, e-mail :muharram.fajrin@um-tapsel.ac.id
}

\begin{abstract}
Abstrak
Limbah kulit kopi belum dimanfaatkan petani secara optimal, kulit kopi bisa digunakan sebagai pakan karena kulit kopi mempunyai kecernaan protein sebesar $65 \%$ dan 51,4 \%.Penelitian ini telah dilaksanakan di kandang aneka ternak Mix Farming Experience (MFE) Fakultas Peternakan Universitas Muhammadiyah Tapanuli Selatan Padangsidimpuan selama 7 minggu, mulai januari 2017 sampai maret 2017.Rancangan yang digunakan adalah Rancangan Acak Lengkap (RAL) dengan jumlah perlakuan $(\mathrm{t})=4$, ulangan $(\mathrm{n})=6$. Adapun susunan perlakuan ransum adalah sebagai berikut: penambahan tepung limbah kulit kopi sebesar 5\%,10\%,15\%. Berdasarkan hasil penelitian terlihat bahwa pengaruh penggunaan tepung limbah kulit kopi (Coffea arabica L) dalam ransum terhadap (indeks putih telur, indeks kuning telur, haugh unit dan warna kuning telur) burung puyuh (Coturnix coturnix javonica) menghasilkan rataan tertinggi pada setiap parameter kualitas telur terdapat pada perlakuan A0 (penambahan tepung limbah kulit kopi $0 \%$ ), pada indeks putih telur memiliki rataan tertinggi sebesar 0,15 , pada indeks kuning telur rataan tertinggi sebesar 0,52 , pada haugh unit rataan tertinggi sebesar 61,70 dan rataan tertinggi pada warna kuning telur dengan nilai 4,83 dinyatakan sebagai warna kuning agak pucat dan rataan terendah dalam setiap parameter terdapat pada perlakuan R3 (penambahan tepung limbah kulit kopi 15\%) pada indeks putih telur memiliki rataan terendah sebesar 0,12, pada indeks kuning telur memiliki nilai terendah sebesar 0,37 pada haugh unit memiliki nilai terendah sebesar 59,79 dan pada warna kuning telur memiliki rataan terendah dengan nilai 3,00 yang dinyatakan sebagai warna kuning pucat.
\end{abstract}

Kata Kunci : Limbah Kulit Kopi, Buru Puyuh, Kualitas Telur

\section{PENDAHULUAN}

\section{Latar Belakang}

Peningkatan pertumbuhan penduduk serta penyediaan pangan produk peternakan harus mendapatkan perhatian khusus agar dapat mengimbangi kebutuhan masyarakat dan memenuhi kebutuhan protein hewani yang dibutuhkan oleh masyarakat.Hal ini juga dapat dilihat karena adanya ketidakseimbangan antara permintaan daging yang meningkat dengan ketersediaan yang ada serta pertambahan ternak yang belum mencukupi ketersediaan kebutuhan masyarakat.

Dalam mencegah kekurangan kebutuhan masyarakat terhadap kebutuhan zat gizi tersebut adalah dengan meningkatkan produksi ternak dan memasarkan produk-produk yang berupa daging, telur dan susu dengan dukungan pemerintah dalam membangun subsektor 
pengembangan keanekaragaman ternak yang dapat memenuhi kebutuhan masyarakat. Disamping itu untuk memenuhi kebutuhan zat gizi masyarakat tidak hanya di hasilkan dari ternak sapi, kambing, domba, daging ayam, ternak lain yang dapat memenuhi kebutuhan masyarakat adalah burung puyuh.

Kelebihan usaha beternak burung puyuh dibandingkan dengan beternak ayam petelur dan itik petelur yaitu burung puyuh lebih cepat bertelur, burung puyuh mulai bertelur pada umur 35-42 hari, burung puyuh memiliki daya tahan yang bagus terhadap penyakit, produktifitasnya yang relatif tinggi, kandungan protein telur burung puyuh yang tinggi, harga telur burung puyuh yang stabil, nilai gizi telur dan daging burung puyuh tidak kalah dengan telur dan daging lainnya sehingga dapat memenuhi kebutuhan zat gizi masyarakat.

Burung puyuh merupakan hewan peralihan yang semula bersifat liar kemudian di adaptasikan menjadi hewan yang dapat diternakkan.Burung puyuh tersebut termasuk genus Coturnix.Burung puyuh tersebut hidup dalam keadaan liar di sawah-sawah kering, ladang dan semaksemak. Burung puyuh Jepang yang nama ilmiahnya Coturnix-coturnix javonica merupakan burung puyuh yang dipelihara di Indonesia sebagai usah sambilan maupun sebagai usaha komersil (Anggorodi, 1995).Burung puyuh banyak diternakkan sebagai unggas petelur dikarenakan produksi telurnya mencapai 250 sampai 300 butir perekor pertahunBurung puyuh dalam waktu 41 hari sudah mampu bertelur dan dalam satu tahun burung puyuh dapat menghasilkan tiga sampai empat keturunan.

Kopi merupakan salah satu tanaman yang disukai oleh masyarakat baik di pedesaan mau pun di perkotaan dan memiliki nilai ekonomis yang cukup tinggi. Kopi hidup di dataran tinggi dan membutuhkan suhu yang cukup rendah untuk berkembang biak salah satu tempat di Indonesia yang terdapat banyak tanaman kopi adalah di Sumatera Utara Kabupaten
Tapanuli Selatan terletak di Kecamatan Sipirok.

Menurut (Badan Pusat Statistika Tapanuli Selatan, 2013) kopi yang terdapat di Tapanuli Selatan memiliki lahan kopi yang cukup luas dan berpotensi menghasilkan biji kopi 791,56 ton pertahun. Namun dengan hasil yang begitu banyak, kopi memiliki sudut pandang yang kurang baik untuk lingkungan yaitu limbah kopi.

Limbah sampingan tersebut berupa kulit kopi yang jumlahnya berkisar 5060\%. Kulit kopi bisa dijadikan pakan ternak karena kulit kopi mempunyai kecernaan protein sebesar 65\% (Azmi dan Gunawan, 2006).Limbah kulit kopi belum dimanfaatkan petani secara optimal, kulit kopi bisa digunakan sebagai pakan karena kulit kopi mempunyai kecernaan protein sebesar $65 \%$ dan 51,4 \%.

\section{Tujuan Penelitian}

Penelitian ini bertujuan untuk mengetahui pengaruh penggunaan tepung limbah kulit kopi (Coffea arabica L) dalam ransum terhadap kualitas telur (indeks putih telur, indeks kuning telur, haugh unit dan warna kuning telur) burung puyuh (Coturnix coturnix japonica).

\section{METODE PENELITIAN}

\section{Tempat dan Waktu Penelitian}

Penelitian ini telah dilaksanakan di kandang aneka ternak Mix Farming Experience (MFE) Fakultas Peternakan Universitas Muhammadiyah Tapanuli Selatan Padangsidimpuan selama 7 minggu, mulai Januari 2017 sampai Maret 2017.

\section{Ternak}

Ternak yang digunakan adalah burung puyuh (Coturnix coturnix javonica) yang dipeliharaberumursatuminggu sebanyak 120 ekor dan diletakan lima ekor setiap plot dengan perbandingan satu ekor jantan dan empat ekor betina. Sampel diambil dari populasi puyuh yang diperoleh dari poultry shop, dilakukan pengacakan 
ditempatkan lima ekor setiap petak dan diberi tanda sesuai perlakuan.

\section{Rancangan Penelitian}

Rancangan yang digunakan adalah Rancangan Acak Lengkap (RAL) dengan jumlah perlakuan $(\mathrm{t})=4$, ulangan $(\mathrm{n})=$ 6.Sehingga percobaan terdiri dari $4 \times 6=$ 24 kombinasi perlakuan

Adapun susunan perlakuan ransum adalah sebagai berikut :

A0 : Ransum dengan penggunaan tepung limbah kulit kopi 0\%.

A1 : Ransum dengan penggunaan tepung limbah kulit kopi 5\%

A2 : Ransum dengan penggunaan tepung limbah kulit kopi 10\%.

A3 : Ransum dengan penggunaan tepung limbah kulit kopi 15\%

\section{Alat dan bahan}

Adapun alat yang digunakan yaitu Kandang sebanyak 24 petak,Tempat pakan dan minum, Bola lampu 5 watt untuk pemanasan dan penerangan,Termometer untuk mengukur suhu, Buku dan alat tulis untuk mencatat jumlah ransum,Timbanganelectrik, Ayakan, Sapu lidi untuk membersihkan kandang, Penggiling tepung, Alat ukur jangka sorong untuk mengukur indeks telur, Alat pengukur warnaYolk Colour Fan.

Adapun bahan yang digunakan yaitu Burung puyuh umursatuminggu sebanyak 120 ekor, Air minum yang diberikan secara adlibitum, makan dua sampai tiga kali sehari, Ransum berdasarkan perlakuan, Vaksin dan obat-obatan, Desinfektan (Rhodalon).

\section{Kandang}

Kandangyang digunakan sebanyak 24 petak dengan ukuran $30 \times 30$ x $30 \mathrm{~cm}$ dan setiap petak kandang dilengkapi dengan lampu, tempat pakan dan tempat minum. Sebelum digunakan kandang berikut peralatan (tempat pakan dan minum) didesinfektan terlebi dahulu menggunakan rhodalon.

\section{Ransum}

Pencampuran ransum dilakukan setiap minggu sesuai dengan perlakuan penelitian.Perlakuan diberikan setelah puyuh berumur 6 hari. Bahan penyusun ransum terdiri dari: Tepung jagung kuning, dedak padi, bungkil kedelai, tepung ikan, minyak sawit, tepung kerabang telur, tepung ampas tahu, tepung tempe, garam, tepung limbah kulit kopi sesuai dengan perlakuan $(5 \%, 10 \%, 15 \%)$. Masing - masing bahan pakan dicampur dan kemudian diaduk sampai komponen bahan pakan menyatu.

Prosedur Pembuatan Tepung Limbah Kulit Kopi

Kulit kopi yang digunakan adalah kulit kopi arabika. Adapun proses pembuatan tepung kulit kopi yaitu:

1. Kulit kopi dicuci bersih pada air yang mengalir agar kotoran yang ada pada kulit kopi hilang.

2. Kulit kopi dikeringkan dengan sinarmatahari, pengeringan ini berfungsi untuk mempermudah proses penggilingan.

3. Kulit kopi yang telah kering dihaluskan dengan alat penggilingtepung.

4. Kulit kopi diayak untuk memisahkan serbuk kulit kopi yang halus dengan serbuk kulit kopi yang kasar.

\section{HASIL DAN PEMBAHASAN}

\section{IndeksPutihTelur}

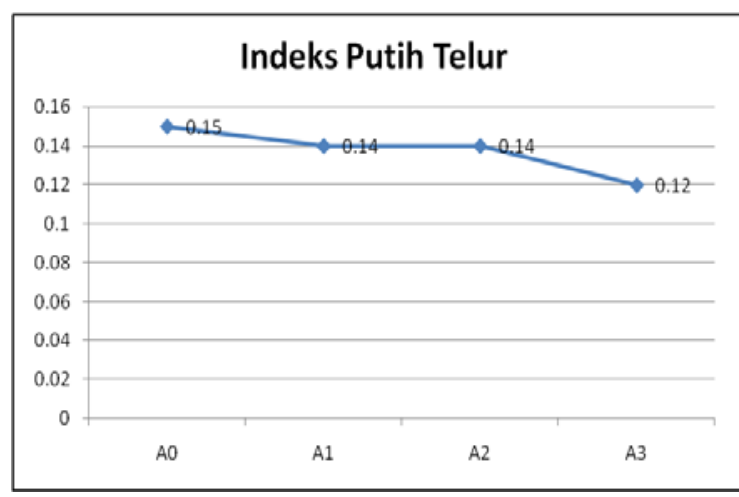

Kurva indeks putih telur 
Indeks putih telur merupakan mutu kesegaran yang diukur dari tebal putih telur dibagi dengan diameter putih telur.Hasil dari Penelitian ini kualitas indeks putih telur yakni berada pada bentuk yang encer.Hasil analisis sidik ragam pada pada penelitian ini Fhitunglebih kecil dibanding Ftabel ini menunjukan perlakuan memberikan pengaruh tidak nyata $(\mathrm{P}>0,05)$ terhadap putih telur.Hal ini disebabkan oleh semakin banyak pemberian tepung limbah kulit kopi dalam ransum maka semakin banyak pula kandungan anti nutrisi seperti kafein dan tanin yang masuk ke dalam saluran pencernaan sehingga dapat menurunkan kualitas telur yang dihasilkan. Hal ini sama seperti yang diutarakan oleh Akmal dan Filawati (2008), salah satu kelemahan penggunaan kulit kopi yang tidak diolah adalah kandungan kafein dan tanin. Pemberian limbah kulit kopi (Coffea arabica $L$ ) dalam ransum kurang disukai oleh ternak di akibatkan warna dari kulit kopi yang hitam sehingga dapat menurunkan konsumsi pakan dan laju pertumbuhan burung puyuh.

\section{IndeksKuningTelur}

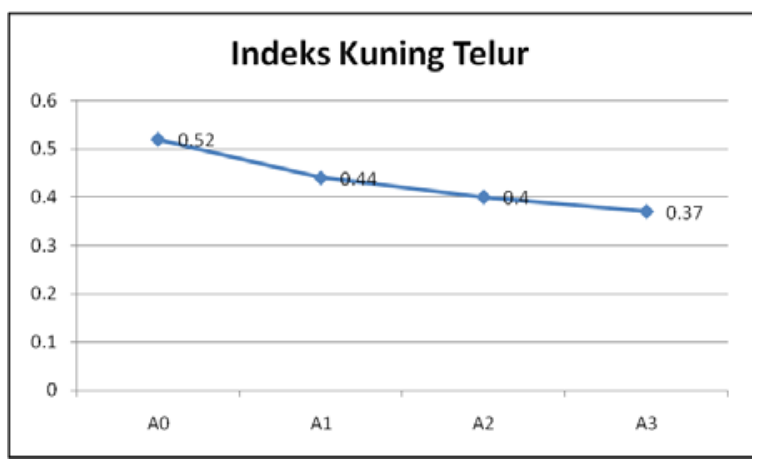

Kurva Indeks Kuning Telur

Indeks kuning telur adalah indeks mutu kesegaran yang diukur tebal dari kuning telur tersebut dibagikan dengan diameter kuning telur sehingga dapat menghasilkan nilai indek kuning telur. Hasil dari penelitian ini dapat dinyatakan indeks kuning telur pada setiap perlakuan makin menurun sehingga kualitas indeks kuning telur tersebut kurang bagus dan hasil analisa sidik ragam pada penelitian ini menunjukan Fhitung lebih kecil dari pada
Ftabel dan dinyatakan tidak nyata $(\mathrm{P}>0,05)$ terhadap indek kuning telur. Hal ini disebabkan oleh pengaruh tepung limbah kulit kopi yang diberikan semakin tinggi maka semakin rendah indek kuning telur yang dihasilkan. Hal ini disebabkan oleh kandungan anti nutrisi yang terdapat pada kulit kopi yaitu kafein dan tanin yang dapat menurunkan kualitas kuning telur, sama seperti pendapat Kumar dan Singh (1991) tanin dapat mengikat protein membentuk ikatan komplek protein tanin sehingga protein tersebut sukar dicerna oleh enzim protease. Menurut (Romanoff and Romanoff, 1963) menyatakan bahwa indeks kuning telur segar berkisar antara 0,30-0,52.

Menurut Tandi (2010) tanin juga mempengaruhi metabolisme karbohidrat dengan mengikat pati sehingga sukar dicerna oleh enzim amilase.

\section{Haugh Unit}

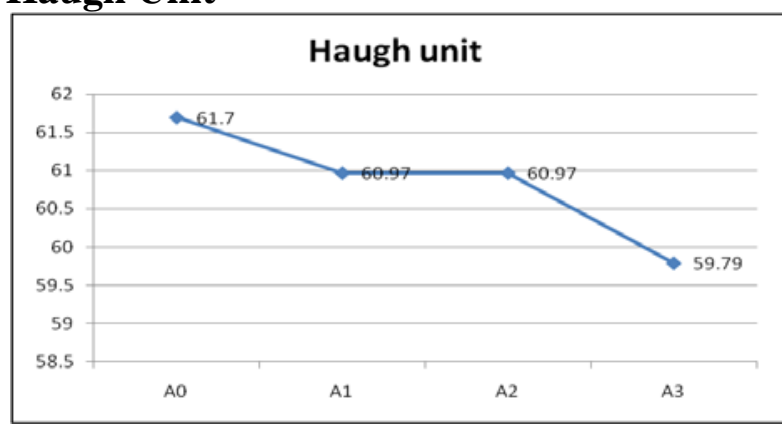

Kurva Haugh Unit

Haugh unit adalah satuan yang digunakan untuk mengetahui kesegaran telur yang dihitung berdasarkan tinggi putih telur dan bobot putih telur (Syamsir, 1994). Berdasarkan penelitian ini rataan HU dari keseluruhan 60,86 Hal ini disebaban oleh rendahnya ketebalan putih telur yang berkisar 0,21 sampai dengan 0,37 dinyatakan sebagai tebal putih telur yang encer disebabkan oleh pengaruh tepung limbah kulit kopi (Coffea arabica L), semakin tinggi penggunaan limbah kulit kopi (Coffea arabica L) maka semakin rendah nilai indek putih telurnya hal ini dikarenakan adanya kandungan anti nutrisi pada kulit kopi seperti kafein dan tanin seperti yang dikatakan oleh Akmal dan Filawati (2008) salah satu kelemahan 
penggunaan kulit kopi yang tidak diolah adalah kandungan kafeindan tanin.Dan hasil analisa sidik ragam pada penelitian ini Fhitung lebih kecil dari pada Ftabel ini menunjukan bahwa haugh unit memberikan pengaruh tidak nyata $(\mathrm{P}>0,05)$. Hal ini disebabkan oleh penggunaan tepung limbah kulit kopi (Coffea arabica L) yang tinggi sehingga dapat menurunkan tebal putih telur dan mempengaruhi nilai haugh unit.Putih telur dan nilai haug unit merupakan logaritma terhadap tinggi Putih telur dan kemudian ditransformasikan kedalam nilai korelasi fungsi berat telur, sehingga apabila nilai indeks albumen tidak nyata maka haugh unit juga tidak nyata.

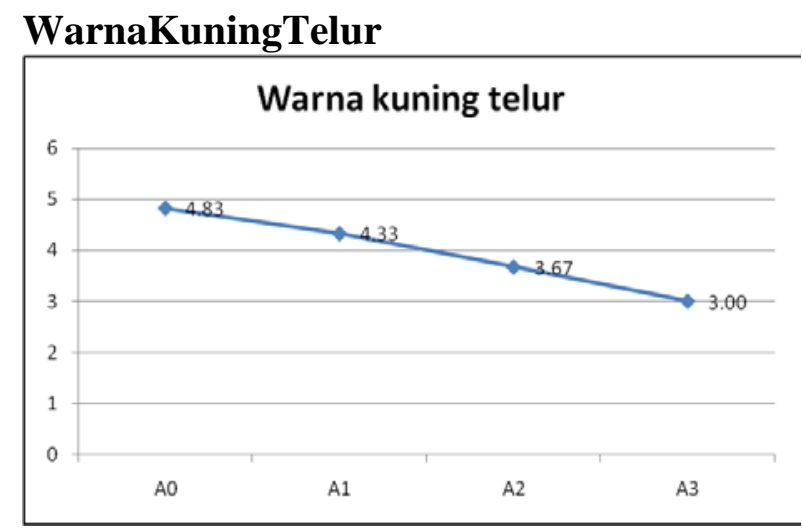

Kurva Warna Kuning Telur

Kuning telur memiliki warna yang bervariasi mulai dari kuning pucat hingga jingga, perubahan kuning telur dipengaruhi oleh pakan yang dimakan dan pigmen. Dari penelitian ini rataan keseluruhan 3,96, dan pada setiap perlakuan nilai rataannya semakin menurun hal ini dapat dinyatakan sebagai kualitas telur burung puyuh kurang baik dan warna kuning telur berada pada warna kuning agak pucat dan warna kuning pucat. Hal ini disebabkan rata rata skor kuning telur yang rendah yang dikategorikan kuning pucat disebabkan oleh tepung limbah kulit kopi (Coffean arabica L), dan kekurangan pigmen karotein pada ransum yang dapat menurunkan skor kuning telur. Hal ini disebabkan kandungan anti nutrisi seperti kafein dan tanin yang menurunkan kualitas putih telur sehingga cairan putih telur menyatu dengan kuning telur dan dapat menurunkan kualitas kuning telur dan mengganggu warna dari kuning telur, sesuai dengan pendapat Romanoff dan Romanoff (1963) perpindahan air secara terus menerus akan menyebabkan viskositas kuning telur menurun sehingga kuning telur menjadi pipih kemudian akan pecah. analisa sidik ragam pada penelitian ini Fhitung lebih kecil dari pada Ftabel ini menunjukan bahwa warna kuning telur memberikan perlakuan tidak nyata $(\mathrm{P}>$ 0,05). Hal ini disebabkan oleh penggunaan tepung limbah kulit kopi tidak mempengaruhi kandungan pigmen karotein sehingga menyebabkan warna kuning telur menurun, sesuai dengan pendapat Chung (2002), bahwa tipe dan jumlah pigmen karotein yang dikonsumsi oleh unggas petelur merupakan faktor utama dalam pigmentasi kuning telur.

\section{RekapitulasiHasilPenelitian}

Berdasarkan Hasil penelitian ini maka dapat dibuat rekapitulasi data yang dapat dilihat pada Tabel dibawah ini.

Keteranga : tn $=$ tidak nyata

\begin{tabular}{|c|c|c|c|c|}
\hline \multirow{2}{*}{$\begin{array}{c}\text { Perla- } \\
\text { kuan }\end{array}$} & $\begin{array}{c}\text { Indeks } \\
\text { putih } \\
\text { telur }\end{array}$ & $\begin{array}{c}\text { Indeks } \\
\text { kuning } \\
\text { telur }\end{array}$ & $\begin{array}{c}\text { Haugh } \\
\text { unit }\end{array}$ & $\begin{array}{c}\text { Warna } \\
\text { kuning } \\
\text { telur }\end{array}$ \\
\hline A0 & $0,15^{\text {tn }}$ & $0,52^{\text {tn }}$ & $61,70^{\text {tn }}$ & $4,83^{\text {tn }}$ \\
\hline A1 & $0,14^{\text {tn }}$ & $0,44^{\text {tn }}$ & $60,97^{\text {tn }}$ & $4,33^{\text {tn }}$ \\
\hline A2 & $0,14^{\text {tn }}$ & $0,40^{\text {tn }}$ & $60,97^{\text {tn }}$ & $3,67^{\text {tn }}$ \\
\hline A3 & $0,12^{\text {tn }}$ & $0,37^{\text {tn }}$ & $59,79^{\text {tn }}$ & $3,00^{\text {tn }}$ \\
\hline
\end{tabular}

Dari Tabel diatas bahwa tepung limbah kulit kopi (Coffeaarabica L) dalam ransum tidak memberikan perlakuan yang nyata terhadap indeks putih telur, indeks kuning telur, haugh unit dan warna kuning telur burung puyuh (Coturnix coturnix javonica). Hal ini disebabkan pemberian limbah kulih kopi (Coffea arabica $L$ ) yang semakin banyak diberikan akan menurunkan kualitas telur sebab adanya kandungan anti nutrisi seperti kafein dan tanin yang dapat mengikat protein sehingga tidak dapat di cerna oleh enzim. Menurut Kumar dan Singh (1991), tanin dapat mengikat protein membentuk ikatan kompleks tanin sehingga protein tersebut 
sukar dicerna oleh enzim protease dan diperkuat oleh pendapat Tandi (2010) tanin juga mempengaruhi metabolisme karbohidrat dengan mengikat pati sehingga sukar dicerna oleh enzim estimasi, sehingga memperoleh hasil yang tidak nyata pada penelitian ini.

\section{KESIMPULAN}

Penggunaan limbah kulit kopi (Coffea arabica L) dalam ransum pada level $0 \%$ $5 \%, 10 \%, 15 \%$ terhadap kualitas telur burung puyuh (Coturnix coturnix javonica), selama penelitian tidak memberikan pengaruh yang nyata terhadap indeks putih telur, indeks kuning telur, haugh unit, dan warna kuning telur

\section{DAFTAR PUSTAKA}

Akmal dan Filawati, 2008.Pemanfaatan Kapang Aspergillus nigersebagai Inokulan Fermentasi Kulit Kopi dengan Media Cair dan Pengaruhnya Terhadap Performans Ayam Broiler. Jurnal Ilmiah IlmuIlmu PeternakanAgustus, 2008, Vol. XI. No.3

Anggorodi, H.R. 1995. Nutrisi Aneka Ternak Unggas. PT Gramedia Pustaka Utama Jakarta

Azmi dan Gunawan. 2006. Hasil-hasil penelitian sistem intergrasi ternak dan tanaman.Prosiding lokakarya hasil pengkajian teknologi pertanian, Balai besar pengkajian dan pengembangan teknologi pertanian, balitbang pertanian bekerjasama dengan Universitas bengkulu. Halaman 91-95

Badan Pusat Statistik.2003. Hasil Produksi Kopi Di Indonesia. Jakarta.

Badan Pusat Statistika Tapanuli Selatan, 2013.Profil KecamatanSipirok.
Badan Standardisasi Nasional. 2008. SNI 3926:2008: Telur Ayam Konsumsi. Jakarta.

Chung, T.K. 2002.Yellow and red carotenoids for eggs yolk pigmentation.10th Annual ASA Southeast Asian Feed Technology and Nutrition Workshop.Merlin Beach Resort, Phuket, Thailand.

Hartadi 1990.Komposisibahanpakanuntuk Indonesia. Gajah mada University press :Yogyakarta.

Imai, C., A. Mowlah., and J. Saito. 1984. Storage Stability of Japanese Quail (Coturnix coturnix japonica) Eggs at Room Temperature.Poultry Science (1986) 65:474-480.

Kumar, R. And M. Singh. 1991. Tannins, their adverse role in ruminant nutrition. J. Agric.Food Chem. 32: $447-453$.

NRC.1995 Nurtien Requirments of Demestic Animals No1 Nutrien Requirements of Poultry $7^{\text {th }} \mathrm{cd} .1977$ NAS.NRC. Washington DC.

Romanoff, A. dan AJ.Rimanoff. 1963. The Avian Egg. Jhon Willeyand sons.Inc. New York.

SNI, 2006.Ransum burung puyuh.Badan Standarisasi Nasional. Jakarta.

Syamsir, E,S Soekarto,S. S Mansjoer. 1994 Studi Komparatif Sifat Mutu dan Fungsional Telur Puyuh dan Telur Ayam Ras.Buletin Tegnologi dan Industri Pangan. Bogor

Tandi, E. J. 2010. Pengaruh Tanin Terhadap Aktivitas Enzim Protease. Seminar Nasional Teknologi Peternakan dan Veteriner.Makasar

Yuwanta, 2007.Kualitas Telur. PT. Pembangunan Jaya.Yogyakarta. 